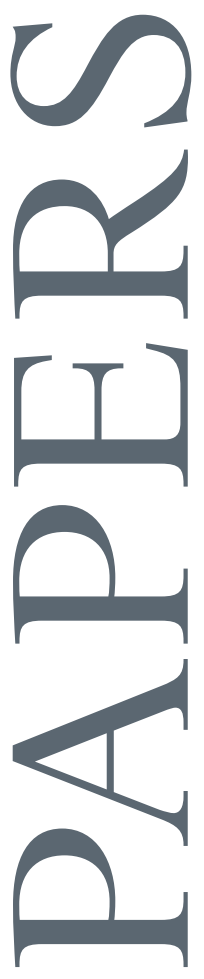

EAST-WEST CENTER WORKING PAPERS

Innovation and Economic Growth Series

No. 10, October 2016

Patents and Technology Transfer through Trade and the Role of Regional Trade Agreements

Keith Maskus

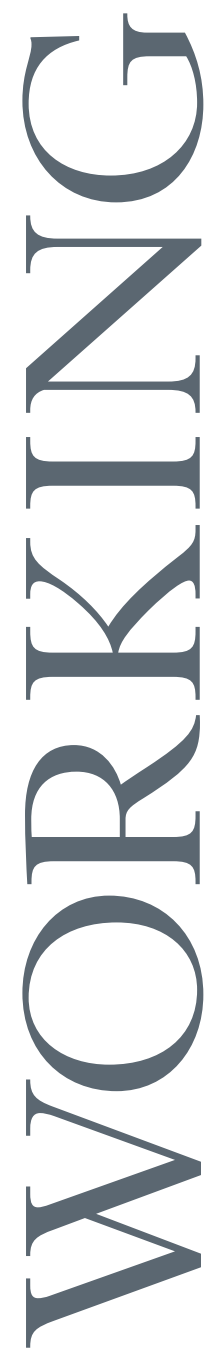

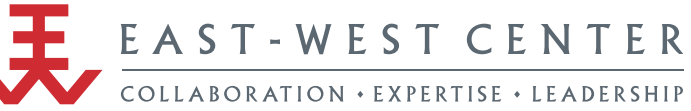




\title{
Patents and Technology Transfer through Trade and the Role of Regional Trade Agreements
}

\author{
Keith Maskus
}

East-West Center Working Papers is an unreviewed and unedited prepublication series reporting on research in progress. The views expressed are those of the author and not necessarily those of the Center. East-West Center Working Papers are circulated for comment and to inform interested colleagues about work in progress at the Center.

Working Papers are available online for free at

EastWestCenter.org/ewcworkingpapers.

The East-West Center promotes better relations and understanding among the people and nations of the United States, Asia, and the Pacific through cooperative study, research, and dialogue. Established by the US Congress in 1960, the Center serves as a resource for information and analysis on critical issues of common concern, bringing people together to exchange views, build expertise, and develop policy options.

The Center's 21-acre Honolulu campus, adjacent to the University of Hawai'i at Mānoa, is located midway between Asia and the US mainland and features research, residential, and international conference facilities. The Center's Washington, DC, office focuses on preparing the United States for an era of growing Asia Pacific prominence.

The Center is an independent, public, nonprofit organization with funding from the US government, and additional support provided by private agencies, individuals, foundations, corporations, and governments in the region.

\section{EastWestCenter.org/publications}

Publications Office| East-West Center 1601 East-West Road | Honolulu, Hawai'i 96848-1601

Tel: 808.944.7145 | Fax: 808.944.7376

EWCBooks@EastWestCenter.org

\begin{abstract}
University of Colorado Boulder Professor of Distinction Keith Maskus has been named the U.S. Department of State chief economist (effective October 2016). Maskus, who was the director of CU Boulder's Program on International Development, is professor of economics and former associate dean for social sciences at the University of Colorado, Boulder, USA. He has been a lead economist in the Development Research Group at the World Bank. He is also a research fellow at the Peterson Institute for International Economics, a fellow at the Kiel Institute for World Economics, and an adjunct professor at the University of Adelaide. He has been a visiting professor at the University of Bocconi and a visiting scholar at the CES-Ifo Institute at the University of Munich and the China Center for Economic Research at Peking University. He serves also as a consultant for the World Bank and the World Intellectual Property Organization and recently chaired a panel of the National Research Council on intellectual property management in standards-setting organizations.
\end{abstract}

Maskus received his $\mathrm{PhD}$ in economics from the University of Michigan in 1981 and has written extensively about various aspects of international trade. His current research focuses on the international economic aspects of protecting intellectual property rights. He is the author of Intellectual Property Rights in the Global Economy, published by the Institute for International Economics, and co-editor of International Public Goods and the Transfer of Technology under a Globalized Intellectual Property Regime, published by Cambridge University Press. A new volume, Private Rights and Public Problems: The Global Economics of Intellectual Property in the 21st Century, was published in 2012 by the Peterson Institute for International Economics.

This paper was presented at the international workshop, funded by the National Science Foundation, on Mega-Regionalism - New Challenges for Trade and Innovation, East-West Center, Honolulu, 20-21 January, 2016. A revised version will be published in Megaregionalism - Innovation and Trade within Global Networks (Dieter Ernst and Michael Plummer, editors), World Scientific Studies/Imperial College Press.

FE EAST - WEST CENTER 


\title{
Patents and Technology Transfer through Trade and the Role of Regional Trade Agreements
}

\author{
Keith Maskus, Department of Economics, University of Colorado Boulder \\ Paper prepared for the MCTI workshop Mega-Regionalism - New Challenges for Trade and \\ Innovation, East-West Center, Honolulu, 20-21 January, 2016
}

\section{Introduction}

Regional trade agreements can have powerful impacts on technology transfer (TT), primarily through their effects on trade in high-technology goods and services, foreign direct investment (FDI), and licensing, all of which are key channels of information diffusion. In that context, regional trade agreements (RTAs) and mega-regionals such as the TPP embody considerable promise for direct expansion of TT, if primarily within the agreement. Moreover, recent econometric evidence largely finds that each of these flows responds positively to strengthened patent laws and other intellectual property rights (IPR), though this conclusion must be conditioned on a variety of factors (Maskus, 2012). These basic observations suggest that there could be an important complementarity between the formation of trade agreements and their IPR standards, a critical question that has not yet attracted much investigation.

In addition, it stands to reason that countries joining RTAs are likely to observe growing within-agreement patent registrations. In that context, patent applications in themselves can facilitate the international diffusion of technological information. Patents are published and may be read by firms seeking to learn new technologies and invent around them, or simply to imitate them if associated patents are not in force in a particular location. Eaton and Kortum (1996), for example, found that OECD countries have derived significant productivity growth from importing knowledge through patents. Moreover, acquiring access to patent rights is a direct form of technology transfer, whether through within-firm or arm's-length licensing. Multinational firms are increasingly loath to license complex technologies without some reasonable legal assurance that accompanying intellectual property rights (IPR) can be protected and will bear some return (Maskus, 2012). Finally, the availability of enforceable patent rights and other IPR can support the development of international technology markets and reduce contracting costs (Arora, et al 2001; Yang and Maskus, 2001).

At the same time, patents embody market power and may be deployed in ways that diminish access to technologies, whether through restrictive licensing practices or unaffordable rights fees. Further, multinational firms may take steps to reduce the ability of local firms to imitate their processes, reducing effective transfers. In response, some governments, especially in emerging and developing economies, erect policies aimed at forcing faster TT or offsetting such market power. Whether such policies are effective or simply deter inward technology flows is context-specific and not well understood (Hoekman, et al 2005). 
Patents and other IPR are even more controversial in their potential impacts on access to technologies that address important quasi-public goods questions, such as affordable medicines, green technologies to combat climate change, and agricultural inputs (Maskus, 2012). To the extent that patents sustain long delays in generic competition they may sharply raise the prices of new medicines, for example. There are complex questions surrounding the roles patents play in these and other areas, with little systematic evidence overall. There is virtually no evidence about whether RTAs may facilitate or diminish access and TT in this regard, yet another shortcoming in available research.

These basic observations point to the importance of thinking about how international strategies might be devised to increase TT on affordable terms in key sectors going forward, with some emphasis on the potential roles RTAs could play. This is the point of departure for the current essay, building on some recent contributions (Barton and Maskus, 2006; Maskus and Saggi, 2013; Maskus and Okediji, 2010). An opportunity for such reflection arises in the recently completed negotiations of the TPP and continuing intergovernmental and NGO work on climate change and access to medicines. In brief, I argue that RTAs could play a positive role if they are supplemented with additional financing commitments, technical assistance, and knowledge sharing. In this context they could be useful complements to larger global initiatives, including an agreement on access to basic science and technology.

In the next section I outline the subject matter, some history, and the important challenges it raises. In the third section I discuss the importance of undertaking additional research to understand the role RTAs may play in conjunction with IPR to enhance or deter technology diffusion. In the fourth section I describe potential policy approaches that could help facilitate future growth in technology diffusion. I conclude in a final section.

\section{Background and History}

The idea that intellectual property protection could increase flows of technology transfer and, ultimately, enhance local development prospects is enshrined in the TRIPS agreement at the

WTO. Specifically, the objectives of TRIPS, set out in Article 7, simply are stated as:

The protection and enforcement of intellectual property rights should contribute to the promotion of technological innovation and to the transfer and dissemination of technology, to the mutual advantage of producers and users of technological knowledge and in a manner conducive to social and economic welfare, and to a balance of rights and obligations.

How, exactly, TRIPS could achieve these goals has been the subject of extensive debate (Maskus, 2012). On the one hand, stronger and more harmonized IPR regulations might raise the certainty of investment, reduce contracting costs, and permit technologies to be deployed more efficiently across borders within production and research networks. On the other hand, elevated patents, plant protection, and digital copyrights might diminish access and raise costs as 
noted above. Both could be true, depending on market and technological circumstances. Clearly, this is a first-order and difficult empirical question, as described in the next section.

Whatever the facts, the underlying TRIPS claims have been expanded by many RTAs, especially those involving the United States and the EU as developed-country partners, by incorporating increasingly complex IPR chapters. As a brief and approximate overview, focusing on US agreements, consider the following history.

- The US-Israel FTA (1985) comprised one paragraph mentioning national treatment and MFN.

- The US-Jordan FTA (2001, at the time considered the "gold standard” for IPR) consists of 5 pages, adding some TRIPS-Plus features in patent standards, pharmaceuticals, test data protection, digital copyrights and anti-circumvention.

- $\quad$ The US-Chile FTA (2004) regularized test data periods and added patents for new plant varieties.

- The US-Australia FTA (2005) added further pharmaceuticals protection, including a "linkage" rule by which patent holders must be notified of potential generic entry. It also reduced the scope of exceptions and limitations in copyrights.

- The US-Korea FTA (2012) put in further limits on CR exceptions, added patents for new uses, removed pre-grant patent opposition, added detailed rules on the rights and obligations of internet service providers, and set out extensive enforcement obligations.

- The TPP (pending) added test data protection in biologic products, incorporated, for the first time in an RTA, extensive trade secrets obligations, and elevated criminal enforcement in IPR. More emphasis is placed on technical assistance in IPR and knowledge sharing.

For its part, the EU has large numbers of RTAs and Partnership Agreements with various partners. Over time these agreements increasingly have focused on IPR issues, with pharmaceuticals, digital copyrights, and geographical indications taking center stage. Recent EU Partnership Agreements with developing economies have extensive language on the importance of knowledge sharing and facilitating the participation of partners in international technology networks (Maskus, 2013).

It is important to note that this growing emphasis on IPR chapters is a component of the growing complexity of RTAs, negotiations of which are more capable of incorporating wider ranges of "behind the border" regulations, such as services provision and access to procurement contracts. In fact, the most striking thing about the TPP as regards technology transfer is not its IPR chapter (though the new and rigorous expectations on trade-secrets protection could be critical). Rather, it is the extensive roster of additional trade and regulatory issues it addresses that could heavily influence the productivity of intellectual property protection. Central among these are (1) additional access commitments in IT markets and technology products; (2) liberalization pledges in producer and financial services; (3) investment protection and investor- 
state dispute resolution; (4) restraints on government policies seeking to force technology transfer; (5) procurement rules; and (6) regulations on the market orientation of state-owned enterprises (SOEs).

In this context, one of the most important - and controversial - elements of megaregional trade agreements is the selection each agreement makes regarding such broader regulatory issues. They may be mutually inconsistent, even where some countries may become partners to two or more agreements. For example, the proposed Regional Comprehensive Economic Partnership (RECEP), led by China, evidently says little about technology transfer rules or SOEs and is markedly less rigorous about IPR in comparison with the TPP. How such differences may work out going forward is an interesting question. Perhaps more important is whether such differences will set up a dynamic pushing more regional countries to abandon one effort for another. Chinese authorities, for example, claim to be open to considering membership in TPP, which presumably would eviscerate RECEP. For present purposes, however, the interesting issue is how such regulatory provisions in mega-regionals may interact with IPR protection.

\section{Trade Agreements and Technology Transfer}

Existing literature strongly supports the view that international technology transfer is increased by growing trade, especially in capital-goods imports, foreign direct investment, and licensing of production rights that share access to intellectual property (Keller, 2004; Hoekman, et al, 2005). There is also evidence that access to global technologies is enhanced by incoming patent applications (Eaton and Kortum, 1996; Peri, 2005) and both temporary and permanent migration of technically skilled workers (Stuen, et al, 2012; Kerr, 2008; Hovhannisyan and Keller, 2015). Much of this transfer is direct and organized through market transactions, within or across firms. However, each of these flows offers considerable scope for technological spillovers, generating localized productivity gains that may in turn induce local innovation and export growth (He and Maskus, 2012; Keller and Yeaple, 2009).

Moreover, there is a solid evidentiary consensus that significant patent reforms, at least as undertaken by major middle-income and emerging economies, attracts increasing amounts of high-technology trade, FDI, and licensing (Ivus, 2010; Maskus, 2012). Studies using aggregate and industry-level data find mixed evidence about the potential for patent reforms to spur innovation in developing countries (Chen and Puttitanun, 2005; Schneider, 2008; Qian, 2010). However, firm-level studies suggest that such reforms can help stimulate local industrial development and export growth in such economies (Branstetter, et al 2006, 2011).

These observations suggest that TT analysts should pose at least two fundamental questions about RTAs. First, it is essential in assessing the impacts of proliferating RTAs (there are now over 400 trade agreements of various kinds notified to the WTO) and emerging megaregional agreements to study their potential for enhancing within-region technology flows and productivity spillovers. It is straightforward to claim that such effects are positive to the extent that RTAs create more trade, FDI, and technology transactions within the region than would 
have happened in their absence, an outcome that varies with agreement characteristics (size, extent of trade liberalization, scope for scale economies, factor prices, absorptive capacity, and other factors). Surprisingly, however, this simple conditional statement has been the subject of relatively very little formal study, particularly as regards FDI and licensing. The limited available evidence indicates that vertical (factor-seeking) FDI between developed and middleincome countries is stimulated by RTAs, but the effects on horizontal (market-seeking) investments are ambiguous (Jang, 2011; Irarrazabal, et al 2009; Bae and Jang, 2013). Bilateral investment treaties (BITs), however, do seem to induce increasing flows among partner countries (Egger and Pfaffermeyer, 2004). All of this suggests that RTAs can serve to increase technology spillovers through their impacts on increasing within-region economic activity. This finding recently has been supplemented by evidence that cross-border patent citations are significantly increased by trade agreements (Jinji, et al 2013). To my knowledge, there are no available econometric studies of RTAs and licensing. Moreover, much of this analysis has been conducted with relatively aggregate data and basic specifications (e.g., gravity), leaving considerable room for improving and refining the available evidence.

Second, and more relevant for this conference, are there greater TT impacts in RTAs with strong rules on intellectual property than in other agreements? Put differently, does implementing a “TRIPS-Plus” regime among RTA partners seem to increase innovation, technology flows and information spillovers more than would be the case in similar RTAs that do not require more than TRIPS standards? This possibility, if borne out in the data, would highlight an important complementarity between partial trade liberalization and patent rights (and perhaps digital copyrights) in enhancing technology diffusion, while informing thinking about potential mega-regional effects. To date there appear to be no studies of these basic questions.

Thus, the first suggestion arising from this paper is to underscore the need for innovation and trade economists to undertake research on whether and how particularly protective IPR rules and other elements of RTAs interact to influence investments in knowledge and knowledge transfer. This research would require hard thinking about how to identify otherwise similar trade agreements and how to measure the stringency of IPR across RTAs, along with determining which industries (or, better, multinational enterprises and local firms) are more likely to be affected by this policy treatment. The kinds of questions that usefully could be posed include the following, among many others.

- $\quad$ Is there an exceptional increase in measures of innovation ( $R \& D$ and patenting) within the higher-IPR RTA and across RTA partners? Does this vary by technology sector (e.g., pharmaceuticals, chemicals, and information echnology) given their particularly elevated standards? Are there any indications of reduced relative use of IPR within the region from nonmember countries? (One might refer to these outcomes as "intellectual property creation and diversion”.)

- $\quad$ Tracking high-technology trade, affiliate activity, and patent citations, are there exceptional increases or decreases in apparent technology transfer within the treatment RTAs? What other factors do such activities depend on? 
- $\quad$ Do there appear to be exceptional changes in the productivity (TFP, market entry, product development, and the like) of local firms within treated RTAs? Do they invest in technology upgrading after RTA implementation, as noted, for example, in Bustos (2011) for Argentine firms with respect to MERCOSUR trade liberalization?

- Is there identifiable evidence of complementarity effects in RTAs that combine high-IPR standards with extensive liberalization commitments in IT goods, FDI and producer services? By complementarity I mean the possibility that RTAs with strong IPR chapters generate exceptional increases in within-agreement trade and FDI. Note that the opposite outcome is possible as well: the market power generated by strong patent rights could permit firms to cut trade, thereby diminishing within-agreement activity.

- $\quad$ To the extent that treatment RTAs generate higher inward flows of FDI to countries with larger policy changes, does this additional source of investment serve to help finance local R\&D and innovation?

\section{Broader Initiatives}

This conference is aimed largely at understanding the roles RTAs and especially megaregional agreements play in various important economic issues. I have argued that such agreements likely expand technology transfer, though available analysis of exactly how that happens is frustratingly limited. Almost surely the great bulk of these information flows comes in the form of market transactions (trade, investment, and licensing) that are encouraged by relaxation of border restrictions within trade agreements. As noted, our knowledge of how IP chapters and other regulatory issues may matter is virtually absent and needs to be addressed by solid research.

This problem is all the more acute in light of the critical importance of knowledge transfers and information diffusion for addressing a range of important global public goods (GPGs) and competition issues in emerging and developing countries. Among the more prominent are affordable access to green technologies, the ability to foster and sustain a generic medicines industry, access to new genetically-based and bio-engineered plant varieties in agriculture, and encouraging the spread of scientific and cultural knowledge. Each of these areas could be the subject of numerous think-pieces and cannot be covered adequately in this short paper. ${ }^{1}$ Rather, in the balance of this draft I address three issues that illustrate key tradeoffs between IPR protection and the achievement of public goods: patent policies in green technologies, greater skilled migration, and broader access to basic science and technology. Needless to say, we have little information about whether and how RTAs per se play a contributory or deterrent role in information flows in these areas, again a clear hole in our knowledge. Thus, the remainder of this piece departs from analyzing RTAs and mega-regionals, except tangentially.

Patents and transfer of green technologies

\footnotetext{
${ }^{1}$ Among many other volumes, see the contributions in Cimoli, et al (2014). My views on these issues and others are spelled out in Maskus (2012).
} 
No issue is more pressing than dealing with climate change by reducing emissions of greenhouse gases (GHGs). This is a complex challenge that will require extensive work beyond IPR policies. There must be considerable investments in clean energy resources and mitigation and adaptation technologies. It is also necessary to facilitate effective diffusion and adaptation of new technologies in developing countries, which account for a rapidly rising share of GHGs emissions. Thus, sustainably transferring appropriate green technologies (GTs) to developing countries and adapting them to local needs form critical elements of addressing climate change. This need for enhancing TT to developing economies has long been a central issue in global negotiations. For example, a proposal was adopted at the December 2009 UNFCC meeting in Copenhagen to establish a \$30 billion annual fund for technology transfer and mitigation assistance, which never materialized. The Paris agreement in December 2015 embodies similar exhortations for a $\$ 100$ billion fund, albeit without specifying how it will come about.

The key question here is the role of IPR, in particular of patents, in this need for greater TT. There is a sharp divide between the developed economies (led by the United States, Japan, and the EU), which remain the overwhelming providers of patented new GTs, and the developing and emerging economies (led by China and India), which need access to them. The former countries see little problem or need for limitations of scope or patentability in this area, while the latter nations prefer accelerated and affordable access through multiple means, including patent exceptions. Global patenting in GTs continues to rise rapidly, with growth rates averaging perhaps 20 percent per year between 1997 and 2008 in clean energy processes and other inventions aimed at environmental management (UNEP, et al 2010). This trend likely has continued as patenting rates have recovered from a dip in the financial recession.

The limited evidence available to date suggests that patents have not been a significant barrier to international TT in key climate-change technologies (Maskus and Okediji, 2010). One reason is that virtually no GT patents have been registered in the poorest countries. Another is that patent ownership within these technology groups tends to be spread widely across countries and firms, suggesting there is little risk of monopoly pricing or anticompetitive behavior (Copenhagen Economics, 2009). Put differently, patents have not significantly diminished within- or across-technology competition on global markets, leaving reasonable choices among substitutes available for potential users. In coming years this could change as investments are made in new forms of environmental technologies. For example, extensive patenting of the enzymes and microorganisms that catalyze biofuels and synthetic fuels could expand, leading to potential patent thickets and transactions costs that increasingly impair access to biotechnological inventions. Perhaps more problematic is that solutions to many specific local ecological needs in poor countries could require particular patented technologies without available substitutes.

In any case, the fact that patents may not yet constitute an access problem does not mean that the current regime is the most effective means of facilitating sufficient innovation and diffusion of GTs. In fact, real private R\&D spending by major developed countries on alternative energy sources and mitigation technologies has been flat for some time, though public investments through research grants and subsidies have increased (Barrett, 2009). Thus, the 
existing global IPR system apparently does not provide enough profit incentives to induce the extensive R\&D needed to develop effective new technologies. Moreover, relatively little of either the public or private investment is aimed at the particular needs of developing countries, because their markets are too small. Finally, even where GTs could be deployed in those countries the available resources to pay for the costs of adapting them to local soil, climate, production, and living conditions are insufficient. Indeed, the poorest countries have the least capacity to invest scarce development resources in costly solutions to domestic environmental concerns, implying a significant mismatch between funding and need.

It is evident from this description that the most effective solutions largely lie outside the IPR system: additional public R\&D funding, a sustainable and internationally distributed tax on carbon use to incentivize new investments in GTs, and improved investment climates in poor countries to encourage specific R\&D programs in local affiliates. Failing such initiatives it is doubtful that working within the patent system can achieve adequate levels of innovation and technology diffusion to combat climate change.

Nonetheless, some systemic reforms could play a useful complementary role in raising the appropriate incentives. All of these ideas are consistent with TRIPS minimum standards and could potentially be implemented within RTAs, even on an experimental basis. Since space is limited I will describe them briefly.

First, there may be gains from modifying patenting conditions to expand access. For example, patent offices in major jurisdictions could be instructed to differentiate application and renewal fees if the applicants commit to effective technology transfer and adaptation. Expedited examinations and mutual recognition of granting decisions would increase returns to R\&D investments. Further, limited extensions to patent duration in developed and major emerging markets, granted midway through an invention's term and with a high renewal fee, could be offered in return for a commitment to low-cost licensing in poor countries. The obvious problem is that such differentiation could invite misclassification of technologies in patent applications. However, this issue could be managed through appropriate fee structures. For example, fees could be effectively differentiated through a partial rebate upon demonstration that the technology has been made available for licensing on reasonable and open terms (such as FRAND) in designated markets. ${ }^{2}$

Second, a complementary approach would be to support voluntary patent pools or networks. Users could acquire the licenses needed for specific mitigation and adaptation technologies from the network in return for royalties paid at ex ante determined rates, differentiated in favor of developing nations. Patent cooperatives can markedly reduce the costs of licensing to multiple markets (Lerner and Tirole, 2004). They are especially helpful where there are many patents on complementary inputs in cumulative inventions, such as solar photovoltaic energy and biofuels. Patent networks could be structured to sustain open licensing in return for an agreed payment, effectively a liability rule regime. To overcome the potential

\footnotetext{
${ }^{2}$ The acronym FRAND refers to "fair, reasonable, and non-discriminatory" and this standard is commonly applied to the licensing of patents deemed essential for making information technologies interoperable across products.
} 
reluctance of patent holders to participate, public subsidization of license fees may be needed to build markets where there are external environmental benefits. Even if voluntary pools failed to attract sufficient private participation, universities and public research institutes could be encouraged to place their technologies into public repositories, accessible to all users in return for licensing fees differentiated by development levels and needs.

Third, as noted above, the need for significant funding to pay for TT and adaptation investments in poor countries is paramount. In this context there is scope for RTA partners to develop their own environmental funds in the event that global participation falls short. Such programs need to adopt principles for managing intellectual property in ways that ensure access on reasonable terms, encourage local adaptation, and incentivize participation by private partners, universities, and NGOs. For example, contractual arrangements could ensure that technology developers can profit from protected sales in non-targeted markets.

\section{Enhancing knowledge flows}

As noted elsewhere, there are several organizational forms that increasingly drive global technology flows (Ernst, 2006; Maskus and Saggi, 2013). Among these are vertical supply chains (VSCs), within which firms share technological processes and standards, global innovation networks (GINs), which feature cross-border collaborative efforts among private enterprises, universities, NGOs, and government institutions, and increasing amounts of temporary movement of skilled technical workers. Each of these is an important means by which firms and institutions in emerging and developing economies can potentially gain greater access to international technological information. Indeed, with VSCs and GINs these institutions can participate in learning and innovation within networks, with potentially large payoffs. Governments in developing countries increasingly emphasize establishing such linkages through innovation and investment policies.

In this context, at least two additional policy ideas could be advanced to strengthen such linkages and RTAs could play an important role in both. First, public agencies that support research should consider opening competition for research grants more widely to permit proposals from international research teams, especially those including participation by scientists from developing countries. To some degree this idea is anticipated in recent EU Partnership Agreements, which sometimes contain provisions for sharing research tasks and building connections (Maskus, 2013).

Second, even relatively modest relaxation of migration restrictions facing skilled workers could generate large international income gains and transfer technologies more effectively. Using a simple framework, I recently calculated the potential effects of a "Western Hemisphere Innovation Zone,” in which each country would increase its work visas for managerial and technical workers by 20 percent, phased in over time (Maskus, 2014). With these 10-year visas permitting free circulation of such workers the potential within-region discounted benefits could reach $\$ 158$ billion over 25 years, against costs of about $\$ 8$ billion. About four percent of these gains, or perhaps $\$ 6$ billion, would come as technology spillovers into developing countries in the region. 


\section{Access to basic science}

The importance of widespread access, including across borders, to the fruits of basic scientific research can scarcely be exaggerated. Basic science generally can be defined as efforts producing knowledge that may have little direct commercial utility but serves as a platform for multiple directions of applied research. Nearly without exception such work is financed by public grants to universities and research institutions in the United States, Europe, Japan, Canada, and other developed economies. However, much of the fruit of basic research has been at least partially privatized through patents, generating concerns about the availability and costs of licenses, while keeping scientists in developing economies detached from its use (Maskus, 2012).

Because of such concerns, some analysts now call for the global community to consider negotiating a treaty on access to basic science and technology (ABST; see Barton and Maskus, 2006 and Maskus, 2012). The basic idea, which attempts to complement the global IPRs system, is to preserve and expand the global basic knowledge commons without overly limiting private incentives to develop commercial technologies. Under an ABST, governments would agree to place the patented results of publicly funded research, defined as knowledge capable of supporting applied science and $R \& D$, into access pools. This would be especially the case in areas of common global concern, such as climate change and genetic research tools. To implement this notion the funding agencies in participating nations would certify that, as a condition for receiving a grant in specific areas of fundamental science, universities and scientists must agree to place the resulting patents into common resource pools. These patents would then be available for license to all competent agents from other member countries under terms worked out in advance, presumably something like FRAND provisions.

Note that an ABST could offer concessional terms to researchers from poor countries, so long as there is no discrimination among applicants within certain development tiers, which could be graduated. Further, the agreement could encourage researchers from member countries to participate in, or apply for, public research grants and related subsidies. It could also permit additional opportunities for temporary migration of scientific researchers in order to facilitate knowledge production. An ABST would also give researchers in other countries access to scientific knowledge and data produced from publicly funded research in any participant.

For reasons discussed elsewhere such an agreement would fit best within the WTO. ${ }^{3}$ However, RTAs could catalyze interest in it by experimenting with regional versions. Such experimentation could involve models of "input liberalization" (scientists sharing access to grants and having increased migration opportunities), "output liberalization” (sharing access to scientific results and data), or both. To reach agreement, however, countries may have to adopt a GATS approach, permitting governments to reserve sensitive areas of technology and to designate different levels of open access. Additional safeguards would have to be worked out, including equitable and efficient sharing of intellectual property.

\footnotetext{
${ }^{3}$ See Maskus (2012), which also discusses related architectural problems, including the scope of subject matter and the need for protecting confidentiality and security.
} 


\section{Concluding Remarks}

In this paper I have set out a series of ideas that might achieve the dual goals of increasing international technology transfer and expanding the global commons for addressing

public goods. At present none of them seems feasible in political terms, except perhaps for the idea of greater funding pools for adapting technologies in poor countries to combat climate change. However, each of them bears promise for achieving such goals, both within RTAs and on a global scale. Some of them, including the idea of an ABST, have achieved initial momentum at forums such as the WIPO Development Agenda.

Ultimately the question posed here is whether to engage in rebalancing the global patenting system more toward access models, at least as regards technological flows and, especially, basic knowledge. To a first approximation this must be a global endeavor, given the public-goods aspects of knowledge and the need for international solutions. However, in certain respects there may be scope for RTAs to weigh in. It is evident that the larger is the economic weight of an RTA the greater will be the impact on technology diffusion. Here, then, lies a potential role for emerging mega-regional agreements. If they pay more attention to policy frameworks for technology transfer they could have significant impacts on global policymaking. Unfortunately, the first such agreement, the TPP, does not move far in that direction.

\section{References}

Arora, Ashish, Andrea Fosfuri, and Alfonso Gambardella. 2001. Markets for Technology: The Economics of Innovation and Corporate Strategy. Cambridge, MA: MIT Press.

Bae, Chankwon, and Yong Joon Jang. 2013. The Impact of Free Trade Agreements on Foreign Direct Investment: The Case of Korea. Journal of East Asian Economic Integration 17: 417-445.

Bustos, Paula. 2011. Trade Liberalization, Exports, and Technology Upgrading: Evidence of the Impact of MERCOSUR on Argentinian Firms. American Economic Review 101: 301-340.

Barton, John H. and Keith E. Maskus. 2006. Economic Perspectives on a Multilateral Agreement on Open Access to Basic Science and Technology. In Economic Development and Multilateral Trade Cooperation, eds. Simon J. Evenett and Bernard M. Hoekman. London: Palgrave MacMillan.

Branstetter, Lee, Ray Fisman and C. Fritz Foley. 2006. Do Stronger Intellectual Property Rights Increase International Technology Transfer? Empirical Evidence from US Firm-Level Panel Data. Quarterly Journal of Economics 121: 321-349.

Branstetter, Lee, Ray Fisman, C. Fritz Foley and Kamal Saggi. 2011. Does Intellectual Property Rights Reform Spur Industrial Development? Journal of International Economics 83: 27-36. 
Chen, Yongmin and Thitima Puttitanun. 2005. Intellectual Property Rights and Innovation in Developing Countries. Journal of Development Economics 78: 474-493.

Cimoli, Mario, Giovanni Dosi, Keith E. Maskus, Ruth L. Okediji, Jerome H. Reichman, and Joseph Stiglitz, editors. 2014. Intellectual Property Rights: Legal and Economic Challenges for Development Oxford: Oxford University Press.

Copenhagen Economics A/S. 2009. Are IPR a Barrier to Transfer of Climate Change Technology? Brussels: Report to Directorate General of Trade, European Commission, January 19.

Eaton, Jonathan and Samuel Kortum. 1996. Trade in Ideas: Patenting and Productivity in the OECD. Journal of International Economics 40: 251-278.

Egger Peter and Michael Pfaffermeyer. 2004. The Impact of Bilateral Investment Treaties on Foreign Direct Investment. Journal of Comparative Economics 32: 788-804.

Ernst, Dieter. 2006. Innovation Offshoring: Asia’s Emerging Role in Global Innovation Networks. Special Report, No. 10, Honolulu: East-West Center.

He, Yin and Keith E. Maskus. 2012. Southern Innovation and Reverse Knowledge Spillovers: A Dynamic FDI Model. International Economic Review, 53: 281-304.

Hoekman, Bernard M., Keith E. Maskus, and Kamal Saggi. 2005. Transfer of Technology to Developing Countries: Unilateral and Multilateral Policy Options. World Development 33: 15871602.

Hovhannisyan, Nune and Wolfgang Keller. 2015. International Business Travel: An Engine of Innovation? Journal of Economic Growth 20(1): 75-104.

Irarrazabal, A., A. Moxnes, and L. Opromolla. 2009. The Margins of Multinational Production and the Role of Intra-firm Trade. CEPR Discussion Paper no. 7145.

Jang, Yong Joon. 2011. The Impact of Bilateral Free Trade Agreements on Bilateral Foreign Direct Investment among Developed Countries. The World Economy 34: 1628-1651.

Jinji, Naoto, Xingyuan Zhang, and Shoji Haruna. 2013. Do Regional Trade Agreements Enhance Technology Spillovers? Kyoto University, Graduate School of Economics, Discussion Paper No. E-12-010.

Keller, Wolfgang. 2004. International Technology Diffusion. Journal of Economic Literature 42: 752-782. 
Keller, Wolfgang and Stephen R. Yeaple. 2009. Multinational Enterprises, International Trade, and Productivity Growth: Firm-Level Evidence from the United States. Review of Economics and Statistics 91: 821-831.

Kerr, William R. 2008. Ethnic Scientific Communities and International Technology Diffusion. Review of Economics and Statistics 90: 518-537.

Lerner, Josh and Jean Tirole. 2004. Efficient Patent Pools. American Economic Review 94: 691711.

Maskus, Keith E. 2012. Private Rights and Public Problems: The Global Economics of Intellectual Property in the $21^{\text {st }}$ Century. Washington: Peterson Institute for International Economics.

Maskus, Keith E. 2013. Assessing the Development Promise of IPRs Provisions in European Union Partnership Agreements," in Josef Drexl, H. Grosse Ruse Khan, and S. Nadde-Phlix, editors, EU Bilateral Trade Agreements and Intellectual Property: for Better or Worse? (Heidelberg: Springer-Verlag).

Maskus, Keith E. 2014. Benefits and Costs of the Science and Technology Targets for the Post2015 Development Agenda. Working paper prepared for the Copenhagen Consensus Project.

Maskus, Keith E. and Ruth L. Okediji. 2010. Intellectual Property Rights and International Technology Transfer to Address Climate Change: Risks, Opportunities and Policy Options. Geneva: International Center for Trade and Sustainable Development, Program on Intellectual Property Rights and Sustainable Development, Issue Paper no. 32.

Maskus, Keith E. and Kamal Saggi. 2013. Global Innovation Networks and Their Implications for the Multilateral Trading System. Geneva: International Center for Trade and Sustainable Development, The E-15 Initiative, working paper.

Peri, Giovanni. 2005. Determinants of Knowledge Flows and their Effects on Innovation. Review of Economics and Statistics 87: 308-322.

Stuen, Eric, Ahmed Mobarak, and Keith E. Maskus. 2012. Skilled Immigration and Innovation: Evidence from Enrolment Fluctuations in U.S. Doctoral Programmes. Economic Journal 122: 1143-1176.

United Nations Environmental Program, European Patent Office, and International Center for Trade and Sustainable Development. 2010. Patents and Clean Energy: Bridging the Gap between Evidence and Policy. Geneva: UNEP.

Yang, Guifang and Keith E. Maskus. 2001. Intellectual Property Rights and Licensing: An Econometric Investigation. Weltwirtschaftliches Arhiv 137: 58-79. 